\title{
PERAN KEPUASAN KONSUMEN MEMEDIASI PENGARUH KUALITAS PELAYANAN DAN CITRA MEREK TERHADAP POSITIVE WORD OF MOUTH
}

\author{
Ni Putu Dema Punkyanti ${ }^{1}$ \\ Ni Ketut Seminari \\ ${ }^{1,2}$ Fakultas Ekonomi dan Bisnis Universitas Udayana, Bali, Indonesia \\ email: demapunkyanti26@gmail.com
}

\begin{abstract}
ABSTRAK
Penelitian ini bertujuan untuk mengetahui pengaruh kualitas pelayanan, dan citra merek terhadap positive word of mouth melalui kepuasan konsumen sebagai variabel memediasi. Penelitian ini dilakukan pada Konsumen Smartphone Samsung di Kota Denpasar, dengan menggunakan teknik Non Probability Sampling, sebanyak 100 responden. Pengumpulan data diperoleh dari hasil penyebaran kuesioner. Teknik analisis data yang digunakan adalah path analysis dan uji sobel. Hasil penelitian menunjukkan bahwa kualitas pelayanan berpengaruh positif dan signifikan terhadap positive word of mouth, citra merek berpengaruh positif dan signifikan terhadap positive word of mouth, kualitas pelayanan berpengaruh positif dan signifikan terhadap kepuasan konsumen, Citra merek berpengaruh positif dan signifikan terhadap kepuasan konsumen, Kepuasan konsumen berpengaruh positif dan signifikan terhadap positive word of mouth, Peran kepuasan konsumen memediasi secara positif dan signifikan hubungan kualitas pelayanan terhadap positive word of mouth, dan Peran kepuasan konsumen memediasi secara positif dan signifikan hubungan citra merek terhadap positive word of mouth.
\end{abstract}

Kata Kunci: citra merek, kepuasan konsumen, kualitas pelayanan, positive word of mouth

\begin{abstract}
This study aims to determine the effesct of service quality, and brand image on positive word of mouth through customer satisfaction as a mediating variable. This research was conducted on Samsung Smartphone Consumers in Denpasar City, using Non-Probability Sampling techniques, as many as 100 respondents. Data collection was obtained from the distribution of questionnaires. Data analysis techniques used are path analysis and multiple test. The results showed that service quality had a positive and significant effect on positive word of mouth, brand image had a positive and significant effect on positive word of mouth, service quality had a positive and significant effect on customer satisfaction, brand image had a positive and significant effect on customer satisfaction, customer satisfaction positive and significant effect on positive word of mouth, the role of customer satisfaction mediates positively and significantly the relationship of service quality to positive word of mouth, and the role of consumer satisfaction positively and significantly relationship brand image to positive word of mouth.
\end{abstract}

Keywords: brand image, customer satisfaction, service quality, positive word of mouth 


\section{PENDAHULUAN}

Persaingan merupakan salah satu fenomena yang sering terjadi antar perusahaan saat ini. Perusahaan dapat dikatakan berkembang apabila perusahan tersebut mampu menghasilkan barang ataupun jasa dengan kualitas yang baik sehingga mampu bersaing dan menjadi market leader (Somantari \& Rastini, 2019). Era globalisasi seperti saat ini menuntut setiap individu untuk dapat berpikiran maju. Karena ilmu pengetahuan teknologi dan informasi serta komunikasi yang terus berkembang di kehidupan sehari-hari ditandai dengan perubahan yang sangat cepat.

Perkembangan bidang teknologi dan informasi meliputi telepon cerdas (smartphone) adalah alat komunikasi yang mempunyai kemampuan tingkat tinggi dengan fungsi yang menyerupai komputer. Sebelum smartphone dikenal luas, pada awalnya terdapat dua produk berbeda yaitu handphone dan Personal Digital Assistant (PDA) (Prawira \& Kerti Yasa, 2018). Smartphone dilengkapi dengan berbagai pilihan fitur seperti menangkap siaran radio dan televisi, perangkat lunak pemutar audio (MP3) dan video, kamera digital, game, layanan internet, menerima email, media sosial dan menyunting dokumen. Jumlah pengguna smartphone di Indonesia dari tahun ke tahun mengalami peningkatan, hal tersebut terdapat pada Gambar 1. yang menunjukan data pertumbuhan pengguna smartphone dari tahun 2013-2018. Pengguna smartphone di Indonesia dari tahun 2013 hingga 2018 terus mengalami peningkatan. Berdasarkan grafik Indonesia sudah melampaui 100 juta pengguna smartphone aktif pada tahun 2018, menjadikannya negara dengan populasi pengguna smartphone terbesar keempat di dunia (setelah China, India, dan Amerika Serikat) (Techinasia, 2019)

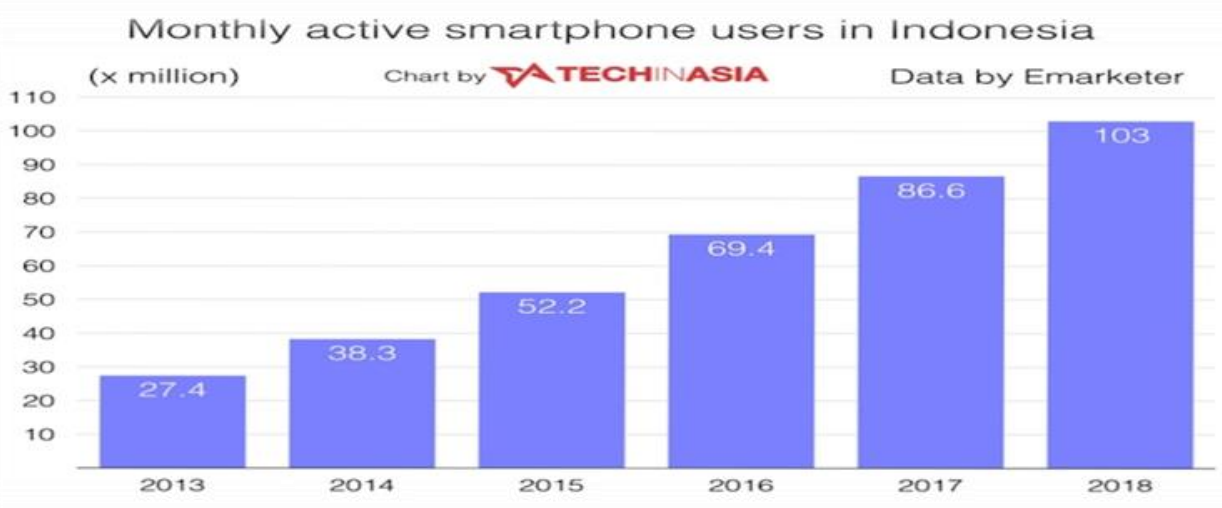

\section{Gambar 1. Diagram Pertumbuhan Pengguna Smartphone di Indonesia}

Sumber : Techinasia, 2019

Bali sebagai salah satu dari provinsi di Indonesia mengalami pertumbuhan penggunaan smartphone yang cepat, terutama di Denpasar yang merupakan Ibukota Provinsi Bali yang menjadi pusat perkembangan teknologi informasi dan komunikasi di Bali. Penduduk yang menggunakan smartphone (telepon seluler) di Kota Denpasar cenderung meningkat setiap tahunnya. 
Tabel 1.

Data Pengguna Teknologi Informasi dan Komunikasi di Provinsi Bali

\begin{tabular}{llll}
\hline Kabupaten/Kota & $\begin{array}{l}\text { Menggunakan } \\
\text { Telepon Seluler }(\boldsymbol{\%})\end{array}$ & $\begin{array}{l}\text { Menggunakan } \\
\text { Komputer } \\
(\boldsymbol{\%})\end{array}$ & $\begin{array}{l}\text { Mengakses Internet } \\
(\boldsymbol{\%})\end{array}$ \\
\hline Jembrana & 75.09 & 16.38 & 16.38 \\
Tabanan & 75.02 & 20.10 & 20.10 \\
1Badung & 82.03 & 31.29 & 31.29 \\
Giayar & 74.90 & 21.27 & 21.27 \\
Klungkung & 64.87 & 17.54 & 17.54 \\
Bangli & 66.52 & 17.52 & 17.52 \\
Karangasem & 75.43 & 11.61 & 11.61 \\
Buleleng & 73.40 & 16.85 & 16.85 \\
Denpasar & 86.76 & 30.79 & 30.79 \\
Jumlah: & 77.51 & 22.44 & 22.44 \\
\hline Sumber: Badan Pusat Statistik Provinsi Bali, 2019 &
\end{tabular}

Tabel 1. menunjukan total pengguna telepon seluler, komputer dan mengakses internet untuk Kabupaten/Kota di Provinsi Bali. Diketahui bahwa Kota Denpasar pengguna telepon seluler tertinggi di bandingkan 8 Kabupaten/Kota yang ada di Bali.

Salah satu metode perusahaan untuk mempertahankan konsumennya adalah word of mouth. Komunikasi dari mulut ke mulut (word of mouth) merupakan aktivitas untuk mempertahankan konsumen yang dipengaruhi oleh faktor sosial yaitu kelompok primer dan pemimpin opini. Kelompok primer yang didalamnya ada interaksi yang bisa dikatakan berkesinambungan, seperti keluarga, teman, tetangga dan teman sejawat (Widiasuari \& Ekawati, 2018). Komunikator kedua yaitu pemimpin opini, disinilah biasanya terjadi peranan opini yang secara langsung menyebarkan informasi menjadi lebih luas yang nantinya mempengaruhi keputusan membeli pada orang yang diberi informasi (Puspita et al. 2016)

Komunikasi positif yang terjadi berupa mulut ke mulut yang saling berinteraksi konsumen satu sama yang lain atau disebut dengan positive word of mouth communication (Widiasuari \& Ekawati, 2018). WOM positif berpengaruh besar terhadap keinginan seseorang untuk menggunakan suatu layanan (Sweeney et al., 2014). Sumardy \& Melone (2011:63) mengemukakan bahwa positive word of mouth merupakan kegiatan pemasaran yang dilakukan oleh sebuah merek agar konsumen dapat membicarakan positif, mempromosikan dan menjual merek tersebut. Persepsi konsumen dalam melakukan kegiatan komunikasi pemasaran yang positif dikarenakan konsumen puas dalam produk tersebut. Komunikasi word of mouth terjadi karena informasi dari temen atau orang terdekat akan lebih dipercaya dibandingkan dengan informasi yang diperoleh dari iklan. Informasi yang diperoleh dari temen, tetangga, atau keluarga akan mengurangi resiko pembelian, sebab pelanggan terlebih dahulu dapat melihat dan mengamati produk yang akan dibelinya dari teman, tetangga atau keluarga (Sutisna, 2003:184). Word of mouth timbul ketika konsumen puas atas produk dan jasa yang dibelinya (Suryani, 2013:169)

Kepuasan konsumen akan menjadi faktor utama sebagai tujuan perusahaan untuk mempertahankan kelangsungan hidup perusahan dalam pasar bisnis dan mampu meningkatkan keunggulan dalam persaingan. Jika ingin mendapatkan 
loyalitas pada konsumen maka hal pertama yang perlu dilakukan adalah menciptakan kepuasan. Kotler \& Keller (2016:153) mendefinisikan kepuasan konsumen adalah perasaan senang atau kecewa seseorang yang berasal dari perbandingan antara kesannya terhadap kinerja (atau hasil) suatu produk dengan harapan-harapannya. Terciptanya kepuasan konsumen akan memberikan manfaat, yaitu hubungan antara perusahaan dan konsumen menjadi baik dan tercipta loyalitas konsumen. Semakin baik kepuasan konsumen maka dapat menimbulkan positive word of mouth (Wahyuni \& Ekawati, 2018). Hasil penelitian Rahmawati \& Suminar (2014), Saraswulandari \& Santika (2013) menyatakan kepuasan konsumen berpengaruh positif terhadap word of mouth. Kepuasan konsumen bergantung pada kualitas produk dan pelayanannya (Gunawan, 2014:68)

Kepuasan konsumen memiliki hubungan yang erat dengan kualitas layanan, kualitas layanan dapat memberikan suatu dorongan pada konsumen untuk menjalin hubungan yang kuat dengan perusahaan. Kualitas pelayanan adalah evaluasi kognitif terhadap produk maupun jasa yang diberikan perusahaan tertentu kepada konsumen dalam jangka waktu yang panjang berdasarkan pada perusahaan yang memberikan komitmen pada kualitas dan secara konsisten memberikan kualitas pelayanan akan menikmati keunggulan persaingan sehingga perusahaan dapat dengan mudah membina loyalitas konsumen dan membina hubungan konsumen dengan sukses (Lovelock \& Wirtz, 2011). Yuni Anita \& Rahanatha (2015) mengungkapkan bahwa terdapat dua faktor yang dapat mempengaruhi kualitas pelayanan jasa, yaitu: expected service atau jasa yang diharapkan dan perceived service atau jasa yang dirasakan. Studi-studi terdahulu (Placeholder1) word of mouth, namun pertanyaan ini bertentangan dengan hasil penelitian yang dilakukan oleh hasil penelitian Ismai (2015) yang menyatakan bahwa citra merek tidak berpengaruh signifikan pada word of mouth.

Hasil penelitian Yana et al. (2015) yang mendapatkan hasil bahwa variabel citra merek berpengaruh terhadap kepuasan konsumen, dengan hasil penelitian yang positif dan signifikan terhadap kepuasan konsumen. Akan tetapi, penelitian yang dilakukan oleh Thomas (2012) menunjukan hasil yang berbeda bahwa brand image memiliki pengaruh yang tidak signifikan terhadap kepuasan konsumen. Hasil penelitian Rahmawati \& Suminar (2014), Saraswulandari \& Santika (2013) menyatakkan kepuasan konsumen berpengaruh positif terhadap word of mouth. Akan tetapi, penelitian yang dilakukan oleh Li (2013) menemukan bahwa tidak ada hubungan yang signifikan antara kepuasan dengan perilaku word of mouth.

Khan et al. (2015) dalam penelitiannya menyatakan bahwa kepuasan merupakan salah satu fakor yang akan menimbulkan perilaku WOM dimana perilaku komunikasi dari mulut ke mulut ini memiliki pengaruh positif terhadap keinginan konsumen dalam membeli suatu produk. Li (2013) menemukan bahwa WOM tidak dipengaruh secara langsung oleh kualitas layanan, melainkan secara tidak langsung melalui peran kepuasan. Mengingat ketidak konsistenan hasil pengujian tersebut, maka peneliti ingin menguji kembali penelitian sebelumnya dengan melibatkan kepuasan sebagai variabel mediasi untuk mengetahui hasil dari pengaruh kualitas pelayanan dan citra merek terhadap positive word of mouth.

Penelitian ini menggunakan empat variabel, yaitu kualitas pelayanan, citra merek, kepuasan konsumen dan positive word of mouth. Keempat variabel tersebut 
memiliki keterkaitan antara satu variabel dengan variabel yang lainnya. Sebagai salah satu perusahaan dalam teknologi dan informasi, kualitas pelayanan yang sesuai dan bahkan melebihi harapan konsumen dapat menciptakan kepuasan bagi konsumen. Selain kualitas pelayanan, citra merek juga dipersepsikan sebanding dengan pelayanan yang diterima oleh konsumen tersebut yang akan menimbulkan kepuasan dibenak konsumen dan kemudian akan mendorong orang-orang disekitarnya untuk membeli smartphone samsung tersebut.

Menawarkan kualitas barang dan jasa sehingga membuat konsumen merasa puas merupakan kunci agar perusahaan dapat bertahan dalam kompetisi yang pada akhirnya konsumen tersebut akan membicarakan produk tersebut pada orang-orang disekitarnya (Mudassar et al., 2012). Kualitas pelayanan berpengaruh positif dan signifikan terhadap Word Of Mouth, artinya semakin baik kualitas pelayanan yang diberikan akan mempengaruhi Word Of Mouth (Indriani \& Nurcaya, 2015). Indriani \& Nurcaya (2015) mengemukan bahwa dalam mempengaruhi konsumen untuk beralih menggunakan produk suatu perusahaan promosi melalui WOM 2 kali lebih efektif dari iklan radio, 4 kali lebih efektif dari pada personal selling dan bahkan 7 kali lebih efektif dibandingkan iklan majalah dan koran. Berdasarkan hasil-hasil penelitian sebelumnya, maka dapat disusun hipotesis sebagai berikut.

$\mathrm{H}_{1}$ : Kualitas Pelayanan berpengaruh positif terhadap Positive Word Of Mouth.

Hasil penelitian Permadi et al. (2014) menyatakan bahwa citra merek berpengaruh positif dan signifikan terhadapat word of mouth, namun pertanyaan ini bertentangan dengan hasil penelitian yang dilakukan oleh hasil penelitian Ismai 2015) yang menyatakan bahwa citra merek tidak berpengaruh signifikan pada word of mouth. Penelitian oleh Febriana \& Rumyeni (2016); Rahayu (2014); dan Ruhamak \& Rahayu (2016) menemukan hasil bahwa komunikasi word of mouth memiliki pengaruh positif dan signifikan terhadap citra merek. Berdasarkan hasilhasil penelitian terdahulu maka dapat disusun hipotesis sebagai berikut.

$\mathrm{H}_{2}$ : Citra Merek berpengaruh positif terhadap Positive Word Of Mouth

Menurut Zeithaml \& Bitner (2013) kualitas pelayanan merupakan hasil penilaian konsumen atau keunggulan layanan secara menyeluruh. Apabila penilaian yang dihasilkan merupakan penilaian yang positif, maka kualitas pelayanan tersebut akan berdampak pada kepuasan. Simon (2016) dalam penelitiannya menyatakan bahwa kualitas pelayanan berpengaruh positif dan signifikan terhadap kepuasan.

Kualitas pelayanan mempunyai tingkat korelasi yang kuat terhadap kepuasan konsumen dan berpengaruh positif terhadap kepuasan konsumen. Ketika konsumen mendapatkan kualitas pelayanan yang terbaik maka konsumen akan semakin merasa puas dan pada akhirnya akan mampu meningkatkan keuntungan perusahaan (Somantari \& Rastini, 2019). Menurut Lee (2013) dalam penelitiannya menyatakan bahwa kualitas pelayanan berpengaruh positif dan signifikan terhadap kepuasan konsumen. Arokiasamy (2013) yang menyebutkan bahwa kualitas pelayanan berpengaruh positif dan signifikan terhadap kepuasan konsumen. Berdasarkan hasil-hasil penelitian sebelumnya, maka dapat disusun hipotesis sebagai berikut.

$\mathrm{H}_{3}$ : Kualitas Pelayanan berpengaruh positif terhadap Kepuasan Konsumen 
Hasil penelitian Yana et al. (2015) yang mendapatkan hasil bahwa variabel citra merek berpengaruh terhadap kepuasan konsumen, dengan hasil penelitian yang positif dan signifikan terhadap kepuasan konsumen. Herliza \& Saputri (2016) serta Thakur \& Singh (2012) dalam penelitiannya juga menyatakan hal yang sama bahwa citra merek berpengaruh secara signifikan terhadap kepuasan konsumen . Widiaswara \& Sutopo (2017) dan Sinaga (2016) menyatakan bahwa citra merek berpengaruh positif dan signifikan terhadap kepuasan konsumen. Akan tetapi, penelitian yang dilakukan oleh Thomas (2012) menunjukan hasil yang berbeda bahwa brand image memiliki pengaruh yang tidak signifikan terhadap kepuasan konsumen. Hal tersebut menyatakan bahwa ternyata brand image belom tentu mampu mempengaruhi kepuasan konsumen. Beberapa hasil penelitian menunjukan bahwa adanya hubungan postif antara citra merek terhadap kepuasan konsumen maka dapat disusun hipotesis sebagai berikut.

$\mathrm{H}_{4} \quad$ : Citra Merek berpengaruh positif terhadap Kepuasan Konsumen

Kepuasan memiliki pengaruh yang signifikan terhadap Word Of Mouth, hal tersebut memiliki arti bahwa Word Of Mouth akan mengalami perubahan apabila kepuasan konsumen mengalami perubahan. Kepuasan konsumen dan perilaku WOM memiliki hubungan positif, dimana jika perusahaan menginginkan perilaku WOM positif dari konsumen, maka perusahaan perlu memberikan tingkat kepuasan yang tinggi kepada konsumen (Primantara, 2017). Hasil penelitian Rahmawati \& Suminar (2014), Saraswulandari \& Santika (2013) menyatakkan kepuasan konsumen berpengaruh positif terhadap word of mouth. Kepuasan berpengaruh secara positif dan signifikan terhadap Word Of Mouth (Ardani \& Suprapti, 2012). Akan tetapi, penelitian yang dilakukan oleh Li (2013) menemukan bahwa tidak ada hubungan yang signifikan antara kepuasan dengan perilaku word of mouth. Berdasarkan hasil-hasil penelitian terdahulu yang memperoleh hasil positif maka dapat disusun hipotesis sebagai berikut.

$\mathrm{H}_{5}$ : Kepuasan Konsumen berpengaruh positif terhadap Positive Word Of Mouth

Pada penelitian yang dilakukan oleh Chaniotakis \& Lymperopoulos (2009), ditemukan bahwa hanya satu dimensi kualitas pelayanan yang mempengaruhi perilaku word of mouth secara langsung, yaitu empati. Empat dimensi lainnya, yaitu keadalan, ketanggapan, jaminan, dan bukti fisik mempengaruhi word of mouth secara tidak langsung. Pada penelitian ini, ditemukan bahwa kepuasan menjadi mediator antara kualitas pelayanan terhadap perilaku word of mouth. Somantari \& Rastini (2019) menemukan adanya hubungan antara kualitas produk, kepuasan konsumen dan word of mouth.

Selain memiliki pengaruh langsung, kualitas layanan juga dapat berpengaruh tidak langsung. dalam penelitiannya menyatakan bahwa kepuasan merupakan salah satu fakor yang akan menimbulkan perilaku word of mouth dimana perilaku komunikasi dari mulut ke mulut ini memiliki pengaruh positif terhadap keinginan pelanggan dalam membeli suatu produk. Li (2013) menemukan bahwa word of mouth tidak dipengaruh secara langsung oleh kualitas layanan, melainkan secara tidak langsung melalui peran kepuasan.

Penelitian ini sejalan dengan penelitian dari Yuni Anita \& Rahanatha (2015) yang menunjukan adanya hubungan antara kualitas pelayanan terhadap WOM 
secara tidak langsung, dimana kepuasan konsumen menjadi variabel mediasi dalam penelitian tersebut. Berdasarkan hasil penelitian yang ditemukan oleh penelitipeneliti sebelumnya, maka dapat disusun hipotesis sebagai berikut.

$\mathrm{H}_{6} \quad$ : Kepuasan Konsumen secara signifikan berperan memediasi Pengaruh

Kualitas Pelayanan Terhadap Positive Word of Mouth

Permadi et al. (2014) dalam penelitiannya menyimpulkan bahwa dengan citra merek yang kuat maka akan mempengaruhi word of mouth pada konsumennya. Selain mempengaruhi word of mouth, citra merek juga dapat mempengaruhi kepuasan konsumen secara signifikan (Radita Herliza \& Saputri, 2016). Hasil penelitian Widiaswara \& Sutopo (2017) dan Sinaga (2016) menyatakan bahwa citra merek berpengaruh positif dan signifikan terhadap kepuasan konsumen.

Kepuasan konsumen dinilai berdasarkan evaluasi persepsi pelayanan yang berhubungan dengan pengalaman memakai produk smartphone samsung tersebut, sehingga semakin puas tingkat kepuasan konsumen maka semakin positive word of mouth produk smartphone samsung tersebut, hal ini didukung hasil penelitian Mismiwati (2016) yang menyatakan kepuasan konsumen, kualitas produk, dan experiential marketing berpengaruh positif terhadap word of mouth. Berdasarkan hasil-hasil penelitian terdahulu yang memperoleh hasil positif maka dapat disusun hipotesis sebagai berikut. Berdasarkan hasil-hasil penelitian terdahulu yang memperoleh hasil positif maka dapat disusun hipotesis sebagai berikut.

$\mathrm{H}_{7}$ : Kepuasan Konsumen secara signifikan berperan memediasi Pengaruh citra merek Terhadap Positive Word of Mouth

\section{METODE PENELITIAN}

Penelitian ini dilakukan di Kota Denpasar yang merupakan Ibukota Provinsi Bali. Kota Denpasar memiliki pengguna telepon seluler dapat dikatakan cukup tinggi sebesar 86.76 persen. Tingginya intensitas jumlah pasar yang tinggi di Kota Denpasar dinilai sesuai untuk dijadikan lokasi penelitian. Adapun yang menjadi obyek dari penelitian ini adalah kualitas pelayanan, citra merek, kepuasan konsumen dan positive word of mouth pada konsumen Smartphone Samsung di Kota Denpasar.

Populasi dalam penelitian ini adalah seluruh Penduduk di Kota Denpasar yang sudah membeli produk Smartphone Samsung dengan jumlah yang tidak diketahui secara pasti (infinite). Beberapa aturan dalam penentuan jumlah sampel, antara lain: ukuran sampel berkisar antara 30-500, untuk sampel yang dipecah menjadi beberapa kategori minimal sebanyak 30 sampel dalam kategori, dalam penelitian multivariat ukuran sampel sebaiknya dikalikan 5-10 dibandingkan dengan jumlah indikator variabel di dalam studi. Penelitian ini menggunakan 14 indikator maka ukuran sampelnya pada rentan 75-150. Berdasarkan pertimbangan tersebut maka ukuran sampel penelitian ini ditetapkan sebanyak 100 responden.

Teknik penelitian ini menggunakan teknik analisis jalur. Analisis jalur (path analysis) merupakan perluasan penerapan analisis regresi linear berganda untuk memprediksi hubungan kausalitas antar variabel (model kausal) yang telah diterapkan sebelumnya berdasarkan teori. 


\section{HASIL DAN PEMBAHASAN}

Instrumen dalam penelitian ini menggunakan data primer berupa kuesioner sebagai alat pengumpulan data, sehingga perlu dilakukan pengujian validitas dan reliabilitas agar kuesioner tersebut layak digunakan. Instrumen dalam penelitian ini diuji menggunakan uji validitas dan uji reliabilitas. Suatu instrumen dikatakan valid apabila memiliki koefisien korelasi antara butir dengan skor total dalam instrumen tersebut lebih besar dari 0,30 dengan tingkat kesalahan Alpha 0,05.

Tabel 3.

Hasil Uji Validitas Instrumen Penelitian

\begin{tabular}{|c|c|c|c|c|c|c|}
\hline No & Variabel & $\begin{array}{l}\text { Indikator } \\
\text { Penelitian }\end{array}$ & $\begin{array}{c}\text { Item } \\
\text { Pertanyaan }\end{array}$ & $\begin{array}{l}\text { Korelasi } \\
\text { item }\end{array}$ & $\begin{array}{l}\text { Sig.(2- } \\
\text { tailed) }\end{array}$ & Keterangan \\
\hline \multirow[t]{5}{*}{1.} & $\begin{array}{l}\text { Kualitas } \\
\text { Pelayanan }\end{array}$ & Buki Fisik & $\mathrm{X} 1.1$ & 0,923 & 0,000 & Valid \\
\hline & (X1) & Keandalan & $\mathrm{X} 1.2$ & 0,876 & 0,000 & Valid \\
\hline & & Daya Tanggap & $\mathrm{X} 1.3$ & 0,841 & 0,000 & Valid \\
\hline & & Jaminan & X1.4 & 0,929 & 0,000 & Valid \\
\hline & & Empati & $\mathrm{X} 1.5$ & 0,903 & 0,000 & Valid \\
\hline \multirow[t]{3}{*}{2.} & Citra & Recognition & $\mathrm{X} 2.1$ & 0,805 & 0,000 & Valid \\
\hline & Merek (X2) & Reputation & $\mathrm{X} 2.2$ & 0,903 & 0,000 & Valid \\
\hline & & Affinity & $\mathrm{X} 2.3$ & 0,868 & 0,000 & Valid \\
\hline \multirow[t]{3}{*}{3.} & $\begin{array}{c}\text { Kepuasan } \\
\text { Konsumen }\end{array}$ & $\begin{array}{l}\text { Confirmation of } \\
\text { Expetation }\end{array}$ & M.1 & 0,834 & 0,000 & Valid \\
\hline & (M) & $\begin{array}{c}\text { Comparison to } \\
\text { Ideal }\end{array}$ & M.2 & 0,884 & 0,000 & Valid \\
\hline & & $\begin{array}{c}\text { Overall } \\
\text { Satisfaction }\end{array}$ & M.1 & 0,953 & 0,000 & Valid \\
\hline \multirow[t]{3}{*}{4.} & $\begin{array}{l}\text { Positive } \\
\text { Word Of }\end{array}$ & $\begin{array}{l}\text { Menceritakan hal- } \\
\text { hal positif }\end{array}$ & Y.1 & 0,935 & 0,000 & Valid \\
\hline & Mouth (Y) & $\begin{array}{l}\text { Merekomendasi } \\
\text { kepada orang lain }\end{array}$ & Y.2 & 0,901 & 0,000 & Valid \\
\hline & & $\begin{array}{l}\text { Mengajak dan } \\
\text { membujuk } \\
\text { konsumen }\end{array}$ & Y.3 & 0,949 & 0,000 & Valid \\
\hline
\end{tabular}

Hasil uji validitas pada Tabel 3. menunjukkan bahwa seluruh instrumen penelitian yang digunakan untuk mengukur variabel kualitas pelayanan, citra merek, kepuasan konsumen, dan positive word of mouth memiliki nilai koefisien korelasi dengan skor total seluruh item pernyataan lebih besar dari 0,30 dengan signifikansi kurang dari 0,05 . Hal ini menunjukkan bahwa butir-butir pernyataan dalam instrument penelitian tersebut valid dan layak digunakan sebagai instrument penelitian.

Nilai Alpha Cronbach dinyatakan reliabel jika nilainya > 0,60. Tabel 4 . menyajikan hasil uji reliabelitas instrumen penelitian. 
Tabel 4.

Hasil Uji Reliabilitas Instrumen Peneitian

\begin{tabular}{clcc}
\hline No. & \multicolumn{1}{c}{ Variabel } & Cronbach's Alpha & Keterangan \\
\hline 1. & Kualitas Pelayanan & 0,934 & Reliabel \\
2. & Persepsi Harga & 0,800 & Reliabel \\
3. & Kepuasan Konsumen & 0,866 & Reliabel \\
4. & Positive Word of & 0,917 & Reliabel \\
& Mouth & & \\
\hline
\end{tabular}

Sumber: Data diolah, 2019

Hasil uji reliabilitas yang disajikan dalam Tabel 4 menunjukkan bahwa seluruh instrumen penelitian memiliki koefisien Cronbach's Alpha lebih dari 0,60. Jadi dapat dinyatakan bahwa seluruh variabel telah memenuhi syarat reliabilitas sehingga dapat digunakan untuk melakukan penelitian. berikut:

Hasil regresi linier berganda untuk struktur I dapat dijelaskan sebagai

$$
\begin{array}{llll}
M & =0,363 X 1+0,515 \times 2 & \\
\mathrm{~S}(\beta) & =(0,108)(0,102) & & \\
\mathrm{t} & =(3,795)(5,396) & & \\
\mathrm{Sig} & =(0,000)(0,000) & & \\
\mathrm{R}^{2} & =0,702 \quad \mathrm{df}=97 \quad \mathrm{~F}=114,013 \quad \mathrm{Sig}=0,000
\end{array}
$$

Hasil regresi linier berganda untuk struktur I dapat dijelaskan sebagai berikut:

$$
\begin{array}{lll}
\mathrm{Y} & =0,410 \mathrm{X} 1+0,316 \mathrm{X} 2+0,263 \mathrm{M} & \\
\mathrm{S}(\beta) & =(0,078)(0,079)(0,069) & \\
\mathrm{t} & =(5,659)(4,109)(3,666) & \\
\mathrm{Sig} & =(0,000)(0,000)(0,000) & \\
\mathrm{R}^{2} & =0,852 \quad \mathrm{df}=96 \quad \mathrm{~F}=184,688 \quad \mathrm{Sig}=0,000
\end{array}
$$

Uji normalitas bertujuan untuk menguji apakah dalam residual dari model regresi yang dibuat berdistribusi normal atau tidak. Regresi yang baik memiliki distribusi normal. Uji yang dapat digunkan adalah Uji Kolmogrov Smirnov. Data dinyatakan berdistribusi normal jika taraf signifikansi lebih besar dari 0,05.

Tabel 5.

Hasil Uji Normalitas Persamaan Regresi 1 dan 2

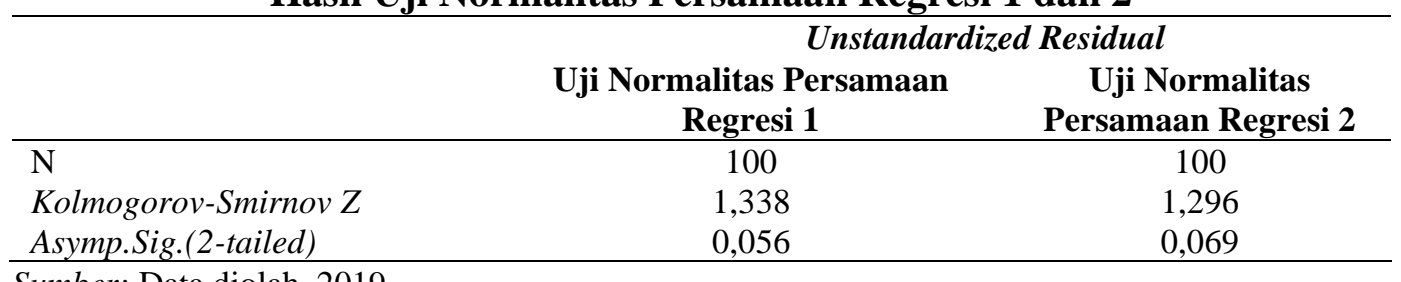

Sumber: Data diolah, 2019

Berdasarkan Tabel 5. Hasil Uji Normalitas Persamaan Regresi 1 dari uji Kolmogorov Smirnov Z sebesar 1,338 sedangkan nilai Asymp. Sig. (2-tailed) sebesar 0,056. Hasil tersebut mengindikasikan bahwa model persamaaan regresi tersebut berdistribusi normal karena nilai Asymp. Sig. (2-tailed) sebesar 0,056 
dimana lebih besar dari nilai alpha yaitu 0,05. Berdasarkan Tabel 5 Hasil Uji Normalitas Persamaan Regresi 2 dari uji Kolmogorov Smirnov Z sebesar 1,296 sedangkan nilai Asymp. Sig. (2-tailed) sebesar 0,069. Hasil tersebut mengindikasikan bahwa model persamaaan regresi tersebut berdistribusi normal karena nilai Asymp. Sig. (2-tailed) sebesar 0,069 dimana lebih besar dari nilai alpha yaitu 0,05 .

Uji heteroskedastisitas bertujuan menguji apakah model regresi terjadi ketidaksamaan varians dari residual satu pengamatan ke pengamatan yang lain. Model regresi yang baik adalah yang tidak mengandung gejala heteroskedastisitas atau mempunyai varians yang homogen. Pengujian ini dilakukan dengan uji Glejser. Tingkat signifikansi dalam uji ini sebesar 0,05, apabila tingkat signifikansi berada di atas 0,05 maka model regresi ini bebas dari masalah heteroskedastisitas. Hasil dari uji ini dapat dilihat dari Tabel 6.

Tabel 6.

Hasil Uji Heteroskedastisitas Persamaan Regresi 1 dan 2

\begin{tabular}{lcccc}
\hline & $\begin{array}{c}\text { Hasil Uji Heteroskedastisitas } \\
\text { Persamaan Regresi 1 }\end{array}$ & $\begin{array}{c}\text { Hasil Uji Heteroskedastisitas } \\
\text { Persamaan Regresi 2 }\end{array}$ \\
\hline Variabel bebas & t hitung & Sig & t hitung & Sig \\
Kualitas Pelayanan & 0,254 & 0,800 & 0,335 & 0,738 \\
Citra Merek & $-1,952$ & 0,054 & $-0,380$ & 0,705 \\
Kepuasan Konsumen & & & $-0,993$ & 0,323 \\
\hline
\end{tabular}

Sumber: Data diolah, 2019

Berdasarkan Tabel 6. Hasil Uji Heteroskedastisitas Persamaan Regresi 1 terlihat bahwa tidak ada pengaruh signifikan variabel bebas kualitas pelayanan dan citra merek terhadap Absolut residual (Abres1). Nilai signifikansi uji t di atas 0,05 menunjukkan data penelitian ini bebas dari heteroskedastisitas. Pada Tabel 4.8 Hasil Uji Heteroskedastisitas Persamaan Regresi 2 terlihat bahwa nilai signifikansi dari variabel kualitas pelayanan, citra merek dan kepuasan konsumen, masingmasing sebesar 0,738, 0,705 dan 0,323. Nilai tersebut lebih besar dari 0,05 yang berarti tidak terdapat pengaruh antara variabel bebas terhadap absolute residual (Abres 2). Dengan demikian, model yang dibuat tidak mengandung gejala heteroskedastisitas.

Uji linearitas digunakan untuk mengetahui pola hubungan antara variabel bebas dengan variabel terikat, mempunyai hubungan yang linear atau tidak secara signifikan. Nilai Sig. Linearity menunjukkan sejauh mana variabel bebas berbanding tepat di garis lurus. Apabila nilai Sig. Linearity lebih kecil dari tingkat signifikansi 0,05, maka regresi linier dapat dipergunakan untuk menjelaskan pengaruh antara variabel-variabel yang ada. Hasil dari Uji Linieritas Ini dapat dilihat dari Tabel 7.

Hasil uji linieritas Nampak bahwa hubungan variabel bebas kualitas pelayanan dan citra merek, variabel mediasi kepuasan konsumen dan variabel terikat positive word of mouth dikatakan linier karena tingkat signifikansinya lebih kecil dari 5 persen $(\mathrm{p}<0,05)$, dengan demikian terbukti bahwa data yang digunakan memenuhi persyaratan linieritas. 
Tabel 7.

Hasil Uji Linieritas

\begin{tabular}{|c|c|c|c|c|c|}
\hline \multirow[t]{2}{*}{ No } & \multirow[t]{2}{*}{ Hubungan Antar Variabel } & \multicolumn{4}{|c|}{$\begin{array}{l}\text { Hasil } \\
\text { Pengujian }\end{array}$} \\
\hline & & $\begin{array}{l}\text { Kriteria } \\
\text { Pengujian }\end{array}$ & $\mathbf{F}$ & Sig & Ket \\
\hline 1. & $\begin{array}{l}\text { Kualitas Pelayanan (X1) } \\
\text { Kepuasan Konsumen (M) }\end{array}$ & Linearity & 154,572 & 0,000 & Linear \\
\hline 2. & $\begin{array}{l}\text { Citra Merek (X2) } \\
\text { Kepuasan Konsumen (M) }\end{array} \longrightarrow$ & Linearity & 187,921 & 0,000 & Linear \\
\hline 3. & $\begin{array}{l}\text { Kualitas Pelayanan }(\mathrm{X} 1) \longrightarrow \\
\text { Positive Word of Mouth }(\mathrm{Y})\end{array}$ & Linearity & 315,020 & 0,000 & Linear \\
\hline 4. & $\begin{array}{l}\text { Citra Merek (X2) } \\
\text { Positive Word of Mouth }(\mathrm{Y})\end{array}$ & Linearity & 287,260 & 0,000 & Linear \\
\hline 5. & $\begin{array}{l}\text { Kepuasan Konsumen }(\mathrm{M}) \\
\text { Positive Word of Mouth }(\mathrm{Y})\end{array}$ & Linearity & 235,528 & 0,000 & Linear \\
\hline
\end{tabular}

Sumber: Data diolah, 2019

Berdasarkan Pelaporan Regresi Struktur 1 seperti yang terdapat di lampiran 6, dapat diketahui bahwa nilai koefisien regresi variabel bernilai positif dengan nilai signifikansi uji t kurang dari 0,05. Hal ini menunjukkan bahwa variabel kualitas pelayanan memiliki pengaruh positif yang signifikan terhadap variabel kepuasan konsumen dan variabel citra merek memiliki pengaruh positif yang signifikan terhadap variabel kepuasan konsumen. Besarnya pengaruh variabel bebas terhadap variabel terikat yang ditunjukkan oleh nilai determinasi total (R Square) sebesar 0,702 mempunyai arti bahwa sebesar 70,2 persen variasi kepuasan konsumen dipengaruhi oleh variasi kualitas pelayanan dan citra merek, sedangkan sisanya sebesar 29,8 persen dijelaskan oleh faktor lain yang tidak dimasukkan ke dalam model.

Berdasarkan Pelaporan Regresi Struktur 2 seperti yang terdapat di lampiran 6, dapat diketahui bahwa nilai koefisien regresi masing-masing variabel bebas bernilai positif dengan nilai signifikansi uji t kurang dari 0,05. Hal ini menunjukkan bahwa semua variabel bebas memiliki pengaruh positif yang signifikan terhadap variabel terikat. Besarnya pengaruh variabel bebas terhadap variabel terikat yang ditunjukkan oleh nilai determinasi total (R Square) sebesar 0,852 mempunyai arti bahwa sebesar 85,2 persen variasi positive word of mouth dipengaruhi oleh variasi kualitas pelayanan, citra merek dan kepuasan konsumen, sedangkan sisanya sebesar 14,8 persen dijelaskan oleh faktor lain yang tidak dimasukkan ke dalam model.

Berdasarkan Tabel 8. dapat diketahui bahwa kualitas pelayanan, berpengaruh langsung terhadap kepuasan konsumen, yaitu dengan signifikansinya sebesar 0,000 atau kurang dari satu persen. Citra merek berpengaruh langsung terhadap kepuasan konsumen, yaitu dengan signifikansinya sebesar 0,000 atau kurang dari satu persen. Variabel kualitas pelayanan berpengaruh langsung terhadap positive word of mouth dengan signifikansi sebesar 0,000 atau kurang dari satu persen. Variabel citra merek berpengaruh langsung terhadap positive word of mouth, yaitu dengan signifikansinya sebesar 0,000 atau kurang dari satu persen. Dan Variabel kepuasan 
konsumen berpengaruh langsung terhadap positive word of mouth, yaitu dengan signifikansinya sebesar 0,000 atau kurang dari satu persen

Tabel 8.

Pengaruh Langsung Variabel Penelitian

\begin{tabular}{|c|c|c|c|c|}
\hline Hubungan Variabel & $\frac{\text { Koefisien regresi }}{\text { Standar }}$ & SE & $\mathbf{T}$ & Sig \\
\hline $\begin{array}{l}\text { Kualitas Pelayanan } \\
\text { Kepuasan Konsumen }\end{array}$ & 0,363 & 0,108 & 3,795 & 0,000 \\
\hline $\begin{array}{l}\text { Citra Merek } \\
\text { Kepuasan Konsumen }\end{array}$ & 0,515 & 0,102 & 5,396 & 0,000 \\
\hline $\begin{array}{l}\text { Kualitas Pelayanan } \\
\text { Positive word of mouth }\end{array}$ & 0,410 & 0,078 & 5,659 & 0,000 \\
\hline $\begin{array}{l}\text { Citra Merek } \\
\text { Positive word of mouth }\end{array}$ & 0,316 & 0,079 & 4,109 & 0,000 \\
\hline $\begin{array}{l}\text { Kepuasan Konsumen } \\
\text { Positive word of mouth }\end{array}$ & 0,263 & 0,069 & 3,666 & 0,000 \\
\hline
\end{tabular}

Sumber: Data diolah, 2019

Berdasarkan Tabel 8. dapat diketahui bahwa kualitas pelayanan, berpengaruh langsung terhadap kepuasan konsumen, yaitu dengan signifikansinya sebesar 0,000 atau kurang dari satu persen. Citra merek berpengaruh langsung terhadap kepuasan konsumen, yaitu dengan signifikansinya sebesar 0,000 atau kurang dari satu persen. Variabel kualitas pelayanan berpengaruh langsung terhadap positive word of mouth dengan signifikansi sebesar 0,000 atau kurang dari satu persen. Variabel citra merek berpengaruh langsung terhadap positive word of mouth, yaitu dengan signifikansinya sebesar 0,000 atau kurang dari satu persen. Dan Variabel kepuasan konsumen berpengaruh langsung terhadap positive word of mouth, yaitu dengan signifikansinya sebesar 0,000 atau kurang dari satu persen

Besarnya nilai $e_{1}=\sqrt{ }(1-0,702)=0,545$ dan besarnya nilai $e_{2}=\sqrt{ }(1-0,852)$ $=0,384$. Koefisen determinasi total persamaan struktural $\mathrm{R}_{\mathrm{m}}^{2}=1-\left(0,545^{2} \mathrm{X} 0,384^{2}\right)$ $=0,960$ mempunyai arti bahwa sebesar 96 persen informasi yang terkandung oleh model yang dibentuk, sedangkan sisanya yaitu 5 persen dijelaskan oleh variabel di luar model yang dibentuk.

Tabel 9.

Pengaruh Langsung, Pengaruh Tidak Langsung serta Pengaruh Total

\begin{tabular}{|c|c|c|c|}
\hline Pengaruh Variabel & $\begin{array}{l}\text { Pengaruh } \\
\text { Langsung }\end{array}$ & $\begin{array}{l}\text { Pengaruh Tidak } \\
\text { langsung }\end{array}$ & Pengaruh Total \\
\hline $\begin{array}{l}\text { Kualitas Pelayanan } \\
\rightarrow \text { Kepuasan Konsumen }\end{array}$ & 0,363 & - & 0,363 \\
\hline $\begin{array}{l}\text { Citra Merek } \\
\rightarrow \text { Kepuasan Konsumen }\end{array}$ & 0,515 & - & 0,515 \\
\hline $\begin{array}{l}\text { Kualitas Pelayanan } \\
\rightarrow \text { Positive word of mouth }\end{array}$ & 0,410 & 0,095 & 0,505 \\
\hline $\begin{array}{l}\text { Citra Merek } \\
\rightarrow \text { Positive word of mouth }\end{array}$ & 0,316 & 0,135 & 0,451 \\
\hline $\begin{array}{l}\text { Kepuasan Konsumen } \\
\rightarrow \text { Positive word of mouth }\end{array}$ & 0,263 & - & 0,263 \\
\hline
\end{tabular}

Sumber: Data diolah, 2019 
Data tersebut menunjukkan bahwa kualitas pelayanan berpengaruh langsung terhadap Positive Word of mouth sebesar 0,410 persen, dengan dimediasi oleh variabel kepuasan konsumen maka didapatkan pengaruh tidak langsung sebesar 0,095 persen, dan pengaruh total sebesar 0,505 persen. Hasil tersebut menunjukkan bahwa kepuasan konsumen memediasi pengaruh kualitas pelayanan terhadap positive word of mouth secara parsial. dan citra merek berpengaruh langsung terhadap positive word of mouth sebesar 0,316 persen, dengan dimediasi oleh variabel kepuasan konsumen maka didapatkan pengaruh tidak langsung sebesar 0,135 persen, dan pengaruh total sebesar 0,415 persen. Hasil tersebut menunjukkan bahwa kepuasan konsumen memediasi pengaruh citra merek terhadap positive word of mouth secara parsial.

Uji sobel digunakan untuk menguji kekuatan pengaruh tidak langsung variabel kualitas pelayanan (X1), citra merek (X2) ke variabel positive word of mouth (Y) melalui variabel kepuasan konsumen (M). Pengaruh tidak langsung variabel kualitas pelayanan (X1), citra merek (X2) ke variabel positive word of mouth (Y) melalui variabel kepuasan konsumen (M) dihitung dengan mengalikan koefisien jalur X terhadap M (a) dengan koefisien jalur M terhadap Y (b) atau ab. Rumus Uji Sobel sebagai berikut:

$$
Z=\frac{a b}{s_{a b}}
$$

Nilai $\mathrm{S}_{\mathrm{ab}}$ dihitung dengan persamaan berikut

$$
a b=\sqrt{b^{2} S a^{2}+a^{2} S b^{2}+S a^{2} S b^{2}}
$$

Berdasarkan hasil analisis pada Lampiran 10 diketahui nilai $a=0,41$; $\mathrm{sa}=0,108 ; \mathrm{b}=0,253 ; \mathrm{sb}=0,069$, dengan menggunakan rumus sobel diatas didapat nilai $\mathrm{Z}$ sebesar 2,5913. Kesimpulan: Oleh karena $\mathrm{z}$ hitung sebesar 2,5913 lebih besar dari 1,96 berarti kepuasan konsumen merupakan variabel yang memediasi pengaruh kualitas pelayanan, terhadap positive word of mouth.

Berdasarkan hasil analisis pada Lampiran 10 diketahui nilai $a=0,549$; $\mathrm{sa}=$ 0,102 ;

$\mathrm{b}=0,253 ; \mathrm{sb}=0,069$, dengan menggunakan rumus sobel diatas didapat nilai $\mathrm{Z}$ sebesar 2,9952. Kesimpulan: Oleh karena z hitung sebesar 2,9952 lebih besar dari 1,96 berarti kepuasan konsumen merupakan variabel yang memediasi pengaruh citra merek, terhadap positive word of mouth.

Penelitian ini terdiri dari 100 responden yang merupakan pelanggan yang pernah membeli Smartphone Samsung responden dalam penelitian ini mayoritas perempuan berjumlah 70 orang dengan persentase sebesar 70,0 persen. Berdasarkan usia, mayoritas responden berusia 18-25 tahun 61 orang dengan persentase sebesar 61,0 persen. Menurut jenjang pendidikan, mayoritas responden berpendidikan SMA sebanyak 74 orang dengan presentase sebesar 74,0 persen. Responden dalam penelitian ini mayoritas pelajar/mahasiswa sebanyak 70 orang responden dengan persentase sebesar 70,0 persen.

Pengaruh antara kualitas pelayanan terhadap positive word of mouth telah diuji dalam penelitian ini, dimana nilai koefisien beta diperoleh sebesar 0,410 
dengan tingkat signifikansi $0,000 \leq 0,05$ sehingga $\mathrm{H}_{0}$ ditolak dan $\mathrm{H}_{1}$ diterima, yang mengindikasikan bahwa kualitas pelayanan berpengaruh positif dan signifikan terhadap positive word of mouth. Hasil tersebut menunjukkan bahwa semakin baik kualitas pelayanan Smartphone Samsung, maka semakin sering pelanggan akan melakukan positive word of mouth terhadap Smartphone Samsung.

Hasil rangkuman penilaian responden yang disajikan dalam deskripsi variabel penelitian menunjukkan bahwa penilaian responden terhadap kualitas pelayanan smartphone samsung di Kota Denpasar berada dalam kategori baik. pelayanan yang diterima konsumen sesuai dengan apa yang diharapkan yang pada akhirnya dapat meningkatkan positive word of mouth smartphone samsung.

Hasil penelitian ini sejalan dengan penelitian sebelumnya yang dilakukan oleh Kualitas pelayanan berpengaruh positif dan signifikan terhadap Word Of Mouth, artinya semakin baik kualitas pelayanan yang diberikan akan mempengaruhi Word Of Mouth (Indriani \& Nurcaya, 2015). Indriani \& Nurcaya (2015) mengemukan bahwa dalam mempengaruhi konsumen untuk beralih menggunakan produk suatu perusahaan promosi melalui WOM 2 kali lebih efektif dari iklan radio, 4 kali lebih efektif dari pada personal selling dan bahkan 7 kali lebih efektif dibandingkan iklan majalah dan koran

Pengaruh antara citra merek terhadap positive word of mouth telah diuji dalam penelitian ini, dimana nilai koefisien beta diperoleh sebesar 0,515 dengan tingkat signifikansi $0,000 \leq 0,05$ sehingga $\mathrm{H}_{0}$ ditolak dan $\mathrm{H}_{1}$ diterima, yang mengindikasikan bahwa citra merek berpengaruh positif dan signifikan terhadap positive word of mouth. Hasil tersebut menunjukkan bahwa semakin baik citra merek Smartphone Samsung, maka semakin sering pelanggan akan melakukan positive word of mouth terhadap Smartphone Samsung.

Hasil rangkuman penilaian responden yang disajikan dalam deskripsi variabel penelitian menunjukkan bahwa penilaian responden terhadap citra merek smartphone samsung di Kota Denpasar berada dalam kategori baik. Responden menilai citra merek smartphone samsung sesuai dengan kualitas yang diberikan. Selain itu citra merek dengan manfaat fungsional yang dirasakan konsumen mampu menimbulkan positive word of mouth Smartphone Samsung.

Hasil penelitian ini sejalan dengan penelitian sebelumnya yang dilakukan oleh Hasil penelitian Permadi et al. (2014) menyatakan bahwa citra merek berpengaruh positif dan signifikan terhadapat word of (mouth. Penelitian oleh Febriana \& Rumyeni, (2016); Rahayu (2014); dan Ruhamak \& Rahayu (2016) menemukan hasil bahwa komunikasi word of mouth memiliki pengaruh positif dan signifikan terhadap citra merek.

Pengaruh antara kualitas pelayanan terhadap kepuasan konsumen telah diuji dalam penelitian ini, dimana nilai koefisien beta diperoleh sebesar 0,363 dengan tingkat signifikansi $0,000 \leq 0,05$ sehingga $\mathrm{H}_{0}$ ditolak dan $\mathrm{H}_{1}$ diterima, yang mengindikasikan bahwa kualitas pelayanan berpengaruh positif dan signifikan terhadap kepuasan konsumen. Hasil tersebut menunjukkan bahwa semakin baik kualitas pelayanan Smartphone Samsung, maka semakin sering konsumen akan melakukan kepuasan konsumen terhadap Smartphone Samsung.

Hasil rangkuman penilaian responden yang disajikan dalam deskripsi variabel penelitian menunjukkan bahwa penilaian responden terhadap kualitas 
pelayanan smartphone samsung di Kota Denpasar berada dalam kategori baik. Responden merasa puas dengan fasilitas fisik, ketepatan sales dalam melayani dan menerima pesanan dari konsumen, serta mampu memberikan rasa aman kepada pelanggan.

Hasil penelitian ini sejalan dengan penelitian sebelumnya yang dilakukan oleh Simon (2016) dalam penelitiannya menyatakan bahwa kualitas pelayanan berpengaruh positif dan signifikan terhadap kepuasan. Menurut Lee (2013) dalam penelitiannya menyatakan bahwa kualitas pelayanan berpengaruh positif dan signifikan terhadap kepuasan konsumen. Arokiasamy (2013) yang menyebutkan bahwa kualitas pelayanan berpengaruh positif dan signifikan terhadap kepuasan konsumen.

Pengaruh antara citra merek terhadap kepuasan pelanggan telah diuji dalam penelitian ini, dimana nilai koefisien beta diperoleh sebesar 0,515 dengan tingkat signifikansi $0,000 \leq 0,05$ sehingga $\mathrm{H}_{0}$ ditolak dan $\mathrm{H}_{1}$ diterima, yang mengindikasikan bahwa citra merek berpengaruh positif dan signifikan terhadap kepuasan konsumen. Hasil tersebut menunjukkan bahwa semakin baik citra merek Smartphone Samsung, maka semakin sering konsumen akan melakukan kepuasan konsumen terhadap Smartphone Samsung.

Hasil rangkuman penilaian responden yang disajikan dalam deskripsi variabel penelitian menunjukkan bahwa citra responden terhadap merek smartphone samsung di Kota Denpasar berada dalam kategori baik. Responden merasa puas dengan layanan smartphone samsung yang diterima karena kualitas pelayanan yang diberikan sesuai dengan apa yang ditawarkan sesuai dengan kemampuan beli konsumen.

Hasil penelitian ini sejalan dengan penelitian sebelumnya yang dilakukan oleh Hasil penelitian Yana \& Yusri (2015) yang mendapatkan hasil bahwa variabel citra merek berpengaruh terhadap kepuasan konsumen, dengan hasil penelitian yang positif dan signifikan terhadap kepuasan konsumen. Herliza \& Saputri (2016) serta Thakur \& Singh (2012) dalam penelitiannya juga menyatakan hal yang sama bahwa citra merek berpengaruh secara signifikan terhadap kepuasan konsumen. Widiaswara \& Sutopo (2017) dan Sinaga (2016) menyatakan bahwa citra merek berpengaruh positif dan signifikan terhadap kepuasan konsumen.

Pengaruh antara kepuasan konsumen terhadap positive word of mouth telah diuji dalam penelitian ini, dimana nilai koefisien beta diperoleh sebesar 0,263 dengan tingkat signifikansi $0,000 \leq 0,05$ sehingga $\mathrm{H}_{0}$ ditolak dan $\mathrm{H} 1$ diterima, yang mengindikasikan bahwa kepuasan konsumen berpengaruh positif dan signifikan terhadap positive word of mouth. Hasil tersebut menunjukkan bahwa semakin baik kepuasan konsumen Smartphone Samsung, maka semakin sering konsumen akan melakukan positive word of mouth terhadap Smartphone Samsung.

Hasil rangkuman penilaian responden yang disajikan dalam deskripsi variabel penelitian menunjukkan bahwa penilaian responden terhadap kepuasan konsumen yang menggunakan produk smartphone samsung di Kota Denpasar berada dalam kategori baik. Responden merasa kepuasannya terpenuhi setelah menggunakan produk smartphone samsung yang berkualitas dan harga yang dianggap sebanding dengan manfaat fungsional yang dirasakan sehingga positive word of mouth mengenai layanan smartphone samsung meningkat. 
Hasil penelitian ini sejalan dengan penelitian sebelumnya yang dilakukan oleh Hasil penelitian Rahmawati \& Suminar (2014), Saraswulandari \& Santika (2013) menyatakkan kepuasan konsumen berpengaruh positif terhadap word of mouth. Kepuasan berpengaruh secara positif dan signifikan terhadap WOM Ardani \& Suprapti (2012).

Peran kepuasan konsumen memediasi pengaruh kualitas pelayanan terhadap positive word of mouth Smartphone Samsung telah diuji dalam penelitian ini. Hasil uji pengaruh kualitas pelayanan terhadap positive word of mouth semula bernilai 0,410. Kemudian setelah adanya kepuasan konsumen sebagai variabel mediasi, nilai pada pengaruh kepuasan konsumen terhadap positive word of mouth meningkat menjadi sebesar 0,410 . Uji sobel yang telah dihitung memperkuat hasil tersebut dengan nilai koefisien $\mathrm{z}$ yang diperoleh adalah 2,5913>1,96 sehingga $\mathrm{H}_{0}$ ditolak dan $\mathrm{H}_{6}$ diterima, yang mengindikasikan bahwa kepuasan konsumen memediasi pengaruh kualitas pelayanan terhadap positive word of mouth. Hasil tersebut menunjukkan bahwa kepuasan konsumen dinilai mampu memediasi pengaruh kualitas pelayanan terhadap positive word of mouth Samrtphone Samsung.

Kepuasan mampu menjadi perantara bagi kualitas pelayanan untuk menimbulkan positive word of mouth. Layanan yang berkualitas akan menimbukan kepuasan pada konsumen. Terdapat banyak hal positif yang diterima oleh perusahaan jika perusahaan salah satunya adalah terciptanya positive word of mouth. konsumen yang merasa puas berpotensi untuk merekomendasikan dan mendorong rekan-rekannya untuk menggunakan produk smartphone samsung.

Hasil penelitian ini sejalan dengan penelitian sebelumnya yang dilakukan oleh Khan et al. (2015) dalam penelitiannya menyatakan bahwa kepuasan merupakan salah satu fakor yang akan menimbulkan perilaku WOM dimana perilaku komunikasi dari mulut ke mulut ini memiliki pengaruh positif terhadap keinginan konsumen dalam membeli suatu produk. Yuni \& Rahanatha (2015) yang menunjukan adanya hubungan antara kualitas pelayanan terhadap word of mouth secara tidak langsung, dimana kepuasan pelanggan menjadi variabel mediasi dalam penelitian tersebut.

Peran Kepuasan konsumen memediasi pengaruh citra merek terhadap positive word of mouth Smartphone Samsung telah diuji dalam penelitian ini. Hasil uji pengaruh citra merek terhadap positive word of mouth semula bernilai 0,316. Kemudian setelah adanya kepuasan konsumen sebagai variabel mediasi, nilai pada pengaruh citra merek terhadap positive word of mouth meningkat menjadi sebesar 0,316. Uji sobel yang telah dihitung memperkuat hasil tersebut dengan nilai koefisien $\mathrm{z}$ yang diperoleh adalah 2,9952>1,96 sehingga $\mathrm{H}_{0}$ ditolak dan $\mathrm{H}_{6}$ diterima, yang mengindikasikan bahwa kepuasan konsumen memediasi pengaruh citra merek terhadap positive word of mouth. Hasil tersebut menunjukkan bahwa kepuasan konsumen dinilai mampu memediasi pengaruh citra merek terhadap positive word of mouth Samrtphone Samusng.

Kepuasan mampu menjadi perantara citra merek untuk menimbulkan positive word of mouth. citra konsumen terhadap merek yang sesuai dengan manfaat yang dirasakan konsumen akan menimbukan kepuasan pada konsumen. Terdapat banyak hal positif yang diterima oleh perusahaan jika perusahaan salah satunya adalah 
terciptanya positive word of mouth. konsumen yang merasa puas berpotensi untuk merekomendasikan dan mendorong rekan-rekannya untuk menggunakan produk smartphone samsung.

Hasil penelitian ini sejalan dengan penelitian sebelumnya yang dilakukan oleh Permadi et al. (2014) dalam penelitiannya menyimpulkan bahwa dengan citra merek yang kuat maka akan mempengaruhi word of mouth pada konsumennya. Selain mempengaruhi word of mouth, citra merek juga dapat mempengaruhi kepuasan konsumen secara signifikan Herliza \& Saputri (2016). Hasil penelitian Widiaswara \& Sutopo (2017) dan Sinaga (2016) menyatakan bahwa citra merek berpengaruh positif dan signifikan terhadap kepuasan konsumen.

\section{SIMPULAN}

Kualitas pelayanan berpengaruh positif dan signifikan terhadap positive word of mouth. Hasil ini berarti bahwa semakin baik kualitas pelayanan Smartphone Samsung maka akan meningkatkan Positive word of mouth dari konsumen. Citra merek berpengaruh positif dan signifikan terhadap positive word of mouth. Hasil ini berarti bahwa semakin baik citra merek konsumen terhadap merek Smartphone Samsung maka akan meningkatkan Positive word of mouth dari konsumen. Kualitas pelayanan berpengaruh positif dan signifikan terhadap kepuasan konsumen. Hasil ini berarti bahwa semakin baik kualitas pelayanan Smartphone Samsung maka akan semakin meningkat pula kepuasan konsumen. Citra merek berpengaruh positif dan signifikan terhadap kepuasan konsumen. Hasil ini berarti bahwa apabila semakin baik citra merek konsumen terhadap merek Smartphone Samsung maka akan semakin meningkat kepuasan konsumen. Kepuasan konsumen berpengaruh positif dan signifikan terhadap positive word of mouth. Hasil ini berarti bahwa semakin baik kepuasan yang dirasakan konsumen, maka akan meningkatkan positive word of mouth terhadap smartphone samsung. Peran kepuasaan konsumen memediasi secara positif dan signifikan hubungan kualitas pelayanan terhadap positive word of mouth. Hasil analisis yang diperoleh dari kedua teknik analisis menunjukkan bahwa secara positif dan signifikan kepuasan konsumen mampu memediasi hubungan kualitas pelayanan terhadap positive word of mouth pengguna smartphone samsung di Kota Denpasar, Bali. Peran kepuasaan konsumen memediasi secara positif dan signifikan hubungan citra merek terhadap positive word of mouth. Hasil analisis yang diperoleh dari kedua teknik analisis menunjukkan bahwa secara positif dan signifikan kepuasan konsumen mampu memediasi hubungan hubungan citra merek terhadap positive word of mouth pengguna smartphone samsung di Kota Denpasar, Bali.

\section{REFERENSI}

Ardani, W., \& Suprapti, N. W. S. (2012). Pengaruh Kualitas Pelayanan Terhadap Kepuasan Dan Wom (Studi Di RSUD Wangaya Denpasar). E-Jurnal Manajemen Pada Fakultas Ekonomi Dan Bisnis Universitas Udayana, 1(2), 240-254. 
Arokiasamy, A. R. (2013). Service Quality And Custumer Satisfaction In The Cellular Telecommunication Service Provider In Malaysia. International Refereed Research Journal, 4(2), 10-47.

Chaniotakis, L. E., \& Lymperopoulos, C. (2009). Service Quality Effect on Satisfaction and Word Of Mouth in The Health Care Industry. Journal Managing Service Quality, 2(1), 229-242. https://doi.org/10.7202/1016404ar

Febriana, L., \& Rumyeni. (2016). The Influence of Word of Mouth Communication towards Brand Image of Iphone on Student of Political Science and Social. Business and Economics Research Journal, 2(2), 1-20.

Gunawan, A. S. (2014). Manajemen Pemasaran. Sekolah Tinggi Ilmu Manajemen YKPN.

Herliza, R., \& Saputri, M. E. (2016). Pengaruh Brand Image Terhadap Kepuasan Pelanggan Studi pada Zara di Mall PVJ Bandung. E-Proceeding of Management, 1949-1955.

Herliza, Radita, \& Saputri, M. E. (2016). Pengaruh Brand Image Terhadap Kepuasan Pelanggan Studi pada Zara di Mall PVJ Bandung. E-Proceeding of Management, 1949-1955.

Indriani, S., \& Nurcaya. (2015). Pengaruh Kualitas Pelayanan Terhadap Wom Yang Dimediasi Oleh Kepercayaan Pelanggan Pada Pt. Auto Bagus Rent Car Denpasar. E-Jurnal Manajemen Pada Fakultas Ekonomi Dan Bisnis Universitas Udayana, 4(5), 1301-1321.

Ismai, A. R. (2015). Binational Study of The Impact of Brand Image, Brand Personality and Brand Love and Word of Mouth: The Case Of Fashion Brands an Uk and Switzerland. Journal Business and Economics, 462-417.

Khan, S. A., Ramzan, N., Shoaib, M., \& Mohyuddin, A. (2015). Impact Of Word Of Mouth On Consumer Purchase Intention. Capturing, Analyzing, and Managing Word-of-Mouth in the Digital Marketplace, 27(1), 213-229. https://doi.org/10.4018/978-1-4666-9449-1.ch012

Kotler, P., \& Keller, K. L. (2016). Manajemen Pemasaran. Erlangga.

Lee, H. S. (2013). Major Moderators Influencing The Relationships Of Service Quality, Customer Satisfaction And Customer Loyalty. Asian Social Science, 9(2), 1-11.

Li, S.-C. (2013). Exploring The Relationship Among Service Quality, Customer Loyalty Dan Word Of Mouth For Private Higher Education In Taiwan. Asia Pasific Management Review, 18(4), 375-389.

Lovelock, C., \& Wirtz, J. (2011). Services Marketing: People, Technology, Strategy. Prentice - Hall.

Mismiwati. (2016). Pengaruh Kepuasan Pelanggan, Kualitas Produk, dan Experiential Marketing Terhadap Word Of Mouth Pada Percetakan Sabiluh 
Haq. I-Economic, 2(1), 19-30.

Mudassar, K., Talib, S., Shiqurancheema, \& Raza, M. S. (2012). The Impact Of Service Quality On Customer Satisfaction And The Moderating Role Of Word Of Mouth. African Journal Of Business Management, 7(18), 1751 1756.

Permadi, P. C, Kumadji, S., \& Kusumawati. (2014). Pengaruh Citra Merek Terhadap Word Of Mouth dan Keputusan Pembelian (Survei pada Konsumen Dapoer Mei Galau Jalan Selorejo 83 Malang). Jurnal Administrasi Bisnis, 10(1), 1-7. https://doi.org/10.4324/9781315853178

Permadi, Prima Conny, Kumadji, S., \& Kusumawati, A. (2014). Pengaruh Citra Merek Terhadap Word Of Mouth dan Keputusan Pembelian (Survei pada Konsumen Dapoer Mei Galau Jalan Selorejo 83 Malang). Jurnal Administrasi Bisnis, 10(1), 1-7.

Prawira, B., \& Kerti Yasa, N. (2018). Pengaruh Kualitas Produk, Citra Merek Dan Persepsi Harga Terhadap Minat Beli Produk Smartphone Samsung Di Kota Denpasar. E - Jurnal Manajemen Unud, 3(12), 2343-2344.

Primantara, W. (2017). Peran Kepuasan Memediasi Kualitas Layanan Terhadap Wom Pada Rsu Surya Husadha Denpasar. E-Jurnal Manajemen Pada Fakultas Ekonomi Dan Bisnis Universitas Udayana, 6(7), 3794-3819.

Puspita, D. L., Yulianto, E., \& Sunarti. (2016). Pengaruh Kualitas Produk dan Word Of Mouth Terhadap Keputusan Pembelian. Jurnal Administrasi Bisnis, 34(1), 79-85.

Rahayu, D. D. (2014). Pengaruh Word Of Mouth dan Brand Community Komunitas Sepak Bola di Pekanbaru terhadap Brand Image. Jurnal Ekonomi, 22(1), 116.

Rahmawati, Y, \& Suminar, B. (2014). Pengaruh Kepuasan dan Loyalitas Pelnggan Terhadap Word Of Mouth Pada Pelanggan Honda Motor di Surabaya. Journal of Business and Banking, 4(3), 15-30. https://doi.org/10.4324/9781315853178

Rahmawati, Yuli, \& Suminar, B. (2014). Pengaruh Kepuasan dan Loyalitas Pelnggan Terhadap Word Of Mouth Pada Pelanggan Honda Motor di Surabaya. Journal of Business and Banking, 4(3), 15-30.

Ruhamak, M. D., \& Rahayu, B. (2016). Pengaruh Word Of Mouth terhadap Purchase Intention melalui Brand Image pada Lembaga Kursus Bahasa Inggris Dynamic English Course Pare. Jurnal Ekonomi Universitas Kadiri, l(2), 188-204.

Saraswulandari, I., \& Santika, W. (2013). Keterlibatan Produk Dan Keterlibatan Situasional Dalam Memoderasi Pengaruh Konsumen Terhadap WOM. EJurnal Manajemen Pada Fakultas Ekonomi Dan Bisnis Universitas Udayana, 3(6), 33-52. 
Simon, K. (2016). Pengaruh Kualitas Layanan Terhadap Kepuasan Pelanggan Surya Nalendra Sejahtera Tours \& Travel. Journal Of Management, 1(3), 1526. https://doi.org/10.1017/CBO9781107415324.004

Sinaga, O. S. (2016). Pengaruh Brand Image Dan Kualitas Pelayanan Pegawai Terhadap Kepuasan Pelanggan Pada Warnet Dimensi Pematangsiantar. Jurnal Sultanist, 5(2), 21-29. https://doi.org/10.1017/CBO9781107415324.004

Sinaga, Onita Sari. (2016). Pengaruh Brand Image Dan Kualitas Pelayanan Pegawai Terhadap Kepuasan Pelanggan Pada Warnet Dimensi Pematangsiantar. Jurnal Sultanist, 5(2), 21-29.

Somantari, M., \& Rastini, N. (2019). Peran Kepuasan Memediasi Kualitas Pelayanan dan Persepsi Harga Terhadap WOM Pada Layanan Gojek di Denpasar. E - Jurnal Manajemen Unud, 8(4), 2473-2474.

Sumardy, M. S., \& Melone, M. (2011). The Power of Word of Mouth Marketing (2nd ed.). PT. Gramedia Pustaka Utama.

Suryani, T. (2013). Perilaku Konsumen di Era Internet Implikasinya pada Strategi Pemasaran. Graha Ilmu.

Sutisna. (2003). Perilaku Konsumen dan Komunikasi Pemasaran. Remaja Rosdakarya.

Sweeney, J., Soutar, G., \& Mazzarol, T. (2014). Factors Enhancing Word Of Mouth Influence: Positive And Negative Service Related Messages. European Journal Of Marketing, 48(1), 336 - 359.

Techinasia. (2019). Diagram Pertumbuhan Pengguna Smartphone di Indobesia 2019.

Thakur, S., \& Singh, A. P. (2012). Brand Image, Customer Satisfaction and Loyality Intention: A Study in the Context of Cosmetic Product Among the People Of Central India. Internasional Journal of Multidisciplinary Management Studies, 2(5), 37-50.

Thomas, S. K. (2012). Kepuasan Konsumen yang Dipengaruhi oleh Kualitas Layanan dengan Brand Image Sebagai Variable Perantara: Study Kasus pada Konsumen Rumah Sakit Swasta di Kota Surabaya. Jurnal Mitra Ekonomi Dan Manajemen Bisnis, 3(2), 200-210.

Wahyuni, N. K. S. Y., \& Ekawati, N. W. (2018). Peran Kepuasan Pelanggan Dalam Memediasi Kualitas Pelayanan Terhadap Word Of Mouth. E - Jurnal Manajemen Unud, 7(5), 2823-2855.

Widiasuari, I. A. P. R., \& Ekawati, N. W. (2018). Peran Kepuasan Konsumen Memediasi Pengaruh Kualitas Produk dan Citra Merek Terhadap Positive Word Of Mouth. E - Jurnal Manajemen Unud, 8(4), 2480-2485.

Widiaswara, T, \& Sutopo. (2017). Analisis Pengaruh Kualitas Produk dan Citra 
Merek Terhadap Loyalitas Pelanggan Melalui Kepuasan Pelanggan Sebagai Variabel Intervening. Journal of Management, 6(4), 1-5. https://doi.org/10.1002/ejsp.2570

Widiaswara, Tias, \& Sutopo. (2017). Analisis Pengaruh Kualitas Produk dan Citra Merek Terhadap Loyalitas Pelanggan Melalui Kepuasan Pelanggan Sebagai Variabel Intervening. Diponegoro Journal Of Management, 6(4), 1-5.

Yana, R. D, \& Yusri, A. (2015). Pengaruh Citra Merek terhadap Kepuasan Pelanggan dan Loyalitas Pelanggan (Survei Pada Konsumen Produk Busana Muslim Dian Di Malaysia). Jurnal Administrasi Bisnis (JAB) Universitas Brawijaya, 21(1), 1-7. https://doi.org/10.1145/3132847.3132886

Yana, Ravita Dwi., Suharyono, \& Yusri, A. (2015). Pengaruh Citra Merek terhadap Kepuasan Pelanggan dan Loyalitas Pelanggan (Survei Pada Konsumen Produk Busana Muslim Dian Di Malaysia). Jurnal Administrasi Bisnis (JAB) Universitas Brawijaya, 21(1), 1-7.

Yuni Anita, N. L. N, \& Rahanatha, G. B. (2015). Pengaruh Kualitas Pelayanan Terhadap Wom Melalui Kepuasan Pada PT. Sarana Dewata Courier. Journal of Chemical Information and Modeling, 4(8), 2192-2209. https://doi.org/10.1017/CBO9781107415324.004

Yuni Anita, Ni Luh Nyoman, \& Rahanatha, G. B. (2015). Pengaruh Kualitas Pelayanan Terhadap Wom Melalui Kepuasan Pada PT. Sarana Dewata Courier. E - Jurnal Manajemen Unud, 4(8), 2192-2209.

Zeithaml, V. A., \& Bitner, M. J. (2013). Service Marketing (Internatio). The Mcgraw-Hills Companies, Inc. 